\title{
Simple and rapid spectrophotometric assay of albendazole in pharmaceuticals using iodine and picric acid as CT complexing agents
}

\author{
Nagaraju Swamy, Kanakapura Basavaiah*
}

Department of Chemistry, Manasagangothri, University of Mysore, Mysore, Karnataka, India

\begin{abstract}
Two simple, rapid and inexpensive spectrophotometric methods are described for the determination of albendazole (ALB) in bulk drug and in tablets. The methods are based on charge-transfer (CT) complexation reaction involving ALB as n-donor and iodine as $\sigma$-acceptor (method A) in dichloromethane or picric acid (PA) as $\pi$-acceptor (method B) in chloroform. The absorbance of CT complexes was measured at $380 \mathrm{~nm}$ for method A, and $415 \mathrm{~nm}$ for method B. The optimization of the experimental conditions is described. Under optimum conditions, Beer's law obeyed over the concentration ranges 8.0-240 and 2.4-42 $\mu \mathrm{g} \mathrm{mL}^{-1}$ for method $\mathrm{A}$ and method B, respectively. The apparent molar absorptivity of CT complexes at the respective $\lambda_{\max }$ are calculated to be $1.17 \times 10^{3}$ and $5.22 \times 10^{3} \mathrm{~L} \mathrm{~mol}^{-1} \mathrm{~cm}^{-1}$ respectively, and the corresponding Sandell sensitivity values are 0.2273 and $0.0509 \mathrm{ng} \mathrm{cm}^{-2}$. The limits of detection (LOD) and quantification (LOQ) are calculated to be (0.69 and 2.08), and ( 0.10 and 0.30$) \mu \mathrm{g} \mathrm{mL}^{-1}$ with method A, and method B, respectively. The intra-day and inter-day accuracy expressed as \% RE and precision expressed as \% RSD were less than $3 \%$. The methods were applied to the determination of ALB in tablets.
\end{abstract}

Uniterms: Albendazole/determination. Spectrophotometry/quantitative analysis. Tablets/quantitative analysis. Charge-transfer complexes.

Dois métodos espectrofotométricos, simples, rápidos e de baixo custo são descritos para a determinação do albendazol (ALB) como fármaco e em comprimidos. Os métodos baseiam-se em reação de complexação de transferência de carga (TC) envolvendo ALB como n-doador e iodo como aceptor de $\sigma$ (método A) em diclorometano ou ácido pícrico como $\pi$-aceptor (método B), em clorofórmio. A absorção de complexos TC foi medida em $380 \mathrm{~nm}$ para o método A e $415 \mathrm{~nm}$ para o método B. A otimização das condições experimentais é descrita. Sob condições ideais, a lei de Beer é obedecida nas concentrações entre 8,0 e 240 e 2,4 e $42 \mu \mathrm{g} \mathrm{mL}^{-1}$ para os métodos A e B, respectivamente. A absortividade molar aparente dos complexos de TC no respectivo $\lambda$ max foi calculada como sendo $1,17 \times 10^{3}$ e $5,22 \times 10^{3} \mathrm{~L} \mathrm{~mol}^{-1} \mathrm{~cm}^{-1}$, respectivamente, e os valores de sensibilidade de Sandell correspondentes são 0,2273 e 0,0509 $\mathrm{ng} \mathrm{cm}^{-2}$. Os limites de deteç̧ão (LOD) e quantificação (LOQ) calculados são $(0,69$ e 2,08$)$ e $(0,10$ e 0,30$) \mu \mathrm{g} \mathrm{mL}^{-1}$, com o método A e o método $\mathrm{B}$, respectivamente. A exatidão intra-dia e inter-dia, expressa como \% de erro relativo e precisão expressa como \% DPR foi inferior a 3\%. Os métodos foram aplicados para a determinação de ALB em comprimidos.

Unitermos: Albendazol/determinação. Espectrofotometria/análise quantitativa. Comprimidos/análise quantitativa. Complexos de transferência de carga.

*Correspondence: Kanakapura Basavaiah, Department of Chemistry, University of Mysore, Manasagangotri, Mysore-570006, India. E-mail: kanakapurabasavaiah@gmail.com 


\section{INTRODUCTION}

Albendazole (ALB), a benzimidazole carbamate (methyl-5-propyl thio-1H-benzimidazol-2-yl carbamate) (Figure 1), is a broad spectrum anthelmintic used in the treatment of threadworm, hookworm and tapeworm (International Pharmacopoeia, 1987; Jaime, William, 1988; Rang, Dale, Rither, 1999). The drug was synthesized by Gyurik and Theodorides (Gyurik, Theodorides, 1975) and its anthelmintic activity was reported by Theodorides (1976). The drug is official in British Pharmacopoeia (British Pharmacopoeia, 2009), which describes a potentiometric titration with perchloric acid in formic acid-acetic acid medium. The development of simple, reliable and affordable procedures for assay of drug substances remains a major research area in today's pharmaceutical care and practice (Esimone et al., 2008). Due to its therapeutic importance several techniques have been reported for the determination of ALB in pharmaceuticals, and include non-aqueous titrimetry (Basavaiah, Nagegowda, Ramakrishna, 2004; Laurentis, Milillo, Bruno, 1997), redox titrimetry (Basavaiah, Prameela, 2003a; Basavaiah, Prameela, 2003b; Basavaiah, Prameela, 2004; Basavaiah, Nagegowda, 2004; Basavaiah, Prameela, 2005; Basavaiah, Ramakrishna, Somashekar, 2006; Basavaiah et al., 2006), UV-spectrophotometry (Mandal et al., 1992; Fregonezi-Nery et al., 2001; Oswal et al., 2010; Soto et al., 2010; Tella et al., 2010), high performance liquid chromatography (Sane et al., 1989a; Liawruangrath, Liawruangrath, 1998; Krishnaiah et al., 2001; Atkosar, Altiokka, Goeksel, 2006; Anil et al., 2008), high performance thin layer chromatography (Abd El-Sattar et al., 2005; Varghese, Vasanthi, Ravi, 2011), spectrofluorimetry (Semahat, Beniz, Esma, 2008; Zhao et al., 2008) and voltammetry (Zuhri et al., 1992; De Oliveira, Stradiotto, 2001; Santos et al., 2005).

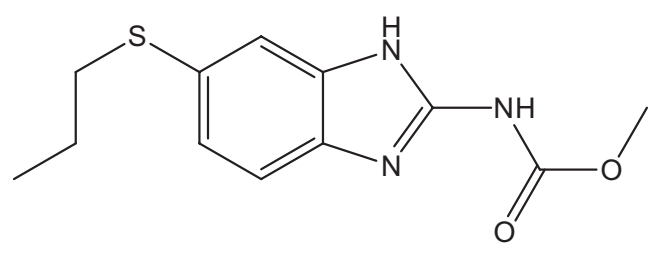

FIGURE 1 - Chemical structure of albendazole.

Several direct and indirect visible spectrophotometric methods based on a variety of reaction chemistries are also found in the literature. A method in which ALB was treated with a measured excess of chloramine-T (CAT) in acid medium followed by the determination of unreacted oxidant by reacting with methyl orange or indigo carmine has been described by Basavaiah and Prameela (2003a). Similar methods involving CAT-methyl-sulphanilic acid (Basavaiah, Prameela, 2003b), in situ bromine-methyl orange (Basavaiah, Prameela, 2004; Basavaiah, Prameela, 2005), $N$-bromosuccinimide (NBS)-methyl orange or indigo carmine (Basavaiah, Ramakrishna, Somashekar, 2006), $N$-chlorosuccinimide (NCS)-iron(II)-thiocyanate (Basavaiah, Nagegowda, 2004), periodate- KBr- methyl orange or indigo carmine (Basavaiah et al., 2006) and perchloric acid-crystal violet (Basavaiah, Nagegowda, Ramakrishna, 2004) have been reported for the indirect assay of ALB in its dosage forms. In two related procedures (Basavaiah et al., 2009), ALB was treated with a measured excess of NBS in $\mathrm{HCl}$ medium, and the unreacted oxidant was reduced by iron(II) and the resulting iron(III) was complexed with thiocyanate or chelated with tiron (4,5-dihydroxy-1,3-benzene disulfonic acid) offering two sensitive methods for ALB.

In contrast, only a few direct methods are available. Zarapkar and Deshpande (1988) have determined ALB in tablets and syrup based on the reduction of Folin-Ciocalteu reagent to a blue colored chromogen, which was measured at $700 \mathrm{~nm}$. There are three reports on the application of ionpair complexation reaction based on spectrophotometry for the assay of ALB in pharmaceuticals. Sane et al. (1989b) have devised four procedures based on this reaction using bromocresol green, bromophenol blue, bromothymol blue and bromophenol red as ion-pair reagents in acidic buffer medium. The ion-pair complexes formed were extracted into chloroform and measured at $420 \mathrm{~nm}$. The methods were applied to tablets and syrup. Thymol blue and five alizarin derivatives (alizarin (I); alizarin red S (II), alizarin yellow (III); quin alizarin (IV), alizarin blue fluorine (V) (Kamel, Barsoum, Sayed, 2008) are the other ion-pair reagents used for the assay of ALB. Sastry et al. (1997) have described extractive spectrophotometric methods for the estimation of some benzimidazole anthelmintics including ALB in pharmaceuticals based on ion pair reaction employing acidic dyes.

Methods based on charge-transfer (CT) complexation reactions have also been reported for ALB. The CT reaction of ALB with $\pi$-acceptor chloranilic acid (CAA) in alcoholic acetone medium was used by Zhao et al. (2001) for the determination of ALB in tablets. Based on similar reaction and employing CAA and 2,3-dichloro5,6-dicyano- $p$ - benzoquinone (DDQ) as $\pi$-acceptors, determination of ALB in tablets has been reported by Refat, Mohammed and Fathi (2011).

Most of the reported indirect spectrophotometric methods described above (Basavaiah, Prameela, 
2004,2003a,2003b; Basavaiah et al., 2006, 2009; Basavaiah, Ramakrishna, Somashekar, 2006; Basavaiah, Nagegowda, Ramakrishna, 2004) are time consuming, and cumbersome since involve multi reagents and multi step reactions, and hence prone to inaccuracy and imprecision. The methods based on ion-pair complexation reactions (Sane et al., 1989b; Sastry et al., 1997; Kamel, Barsoum, Sayed, 2008), though sensitive; suffer from such disadvantages as tedious and timeconsuming extraction step, critical dependence on $\mathrm{pH}$, and aqueous to aqueous-organic phase's ratio. There are also prone to inaccuracies owing to incomplete extraction or formation of emulsion between the hydrocarbon solvent and the drug solution. The reported methods based on CT formation reaction (Zhao et al., 2001; Refat, Mohammed, Fathi, 2011) are less sensitive and applicable over narrow linear ranges.

Despite their wide applicability and ability to form stable and sensitive CT complexes with nitrogenous bases, and particularly pharmaceutical substances (Ebeid et al., 1998; Abou, 2000; Regulska, Tarasiewicz, Puzanowska, 2002; El-Mammli, 2003; El- Yazbi et al., 2003; Abdel-Hay et al., 2004; Karuna et al., 2006; Rajendra, Basavaiah, Vinay, 2011; Johnson, Ukpe, 2011; Pinderjit, Rajanish, Harinder, 2011; Sameer, Basavaiah, 2011; Raghu, Basavaiah, 2012; Prashanth, Basavaiah, 2012) iodine, as a $\sigma$-acceptor and picric acid, a $\pi$-acceptor have not been applied for the spectrophotometric assay of ALB. This paper describes, for the first time, the application of these two reagents to the spectrophotometric determination of ALB. The formed CT complexes between ALB and iodine or picric acid were measured directly in dichloromethane or chloroform medium. The proposed methods have been demonstrated to be superior to the reported methods with respect to speed, simplicity, sensitivity, cost-effectiveness and eco-friendliness.

\section{EXPERIMENTAL}

\section{Apparatus}

A Systronics model 166 digital spectrophotometer (Systronics, Ahmedabad, Gujarat, India) equipped with $1 \mathrm{~cm}$ matched quartz cells was used for all absorbance measurements.

\section{Material}

Pharmaceutical grade ALB (99.7 per cent pure) was received as a gift from Cipla India, Ltd., Mumbai, and used as received. Alworm-400 (Medopharm Ltd., Malur,
India), ABD-400 (Intas Pharma. Ltd. Ahmedabad, India) and Bandy-400 (Mankind Pharma. Ltd., New Delhi, India) tablets were purchased from local commercial sources.

\section{Reagents and chemicals}

All reagents used were of analytical reagent grade, and HPLC grade organic solvents were used throughout the investigation.

$0.3 \%$ Iodine (Merck, Mumbai, India) and $0.05 \%$ picric acid (S.D. Fine chem., Mumbai, India) solutions were prepared separately in dichloromethane (DCM) for method A, and chloroform for method B.

\section{Standard ALB solution}

A stock standard solution containing $1000 \mu \mathrm{g} \mathrm{mL} \mathrm{m}^{-1}$ ALB was prepared by dissolving $100 \mathrm{mg}$ of pure drug in dichloromethane and diluting to volume with the same solvent in a $100 \mathrm{~mL}$ calibrated flask. This was diluted appropriately with same solvent, to get working concentration of $400 \mu \mathrm{g} \mathrm{mL}^{-1}$ in method A. In method B, a $100 \mu \mathrm{g} \mathrm{mL}^{-1} \mathrm{ALB}$ solution was prepared by dissolving $10 \mathrm{mg}$ of pure drug in chloroform and diluting to mark with the same solvent in $100 \mathrm{~mL}$ calibrated flask, and a working concentration of $60 \mu \mathrm{g} \mathrm{mL}^{-1}$ was prepared by diluting with chloroform.

\section{Assay procedures}

\section{Method A (Using iodine, $I_{2}$ )}

Different aliquots of $0.1,0.25,0.5,1.0,2.0,2.5$ and $3.0 \mathrm{~mL}$ of standard ALB solution $\left(400 \mu \mathrm{g} \mathrm{mL}^{-1}\right)$ were accurately transferred to $5 \mathrm{~mL}$ standard flasks using a microburette, and the total volume was adjusted to $3.0 \mathrm{~mL}$ by adding adequate quantity of DCM. One $\mathrm{mL}$ of $0.3 \%$ iodine was added to each flask and the mixture was diluted to the volume with DCM and mixed well. The absorbance of each solution was measured at $380 \mathrm{~nm}$ against a reagent blank after 5 min.

\section{Method B (Using picric acid, PA)}

Aliquots of $0.2,0.5,1.0,2.0,3.0$ and $3.5 \mathrm{~mL}$ of standard ALB solution $\left(60 \mu \mathrm{g} \mathrm{mL}^{-1}\right)$ were accurately added to $5 \mathrm{~mL}$ calibrated flasks using a microburette, and the total volume was adjusted to $3.5 \mathrm{~mL}$ with chloroform. One $\mathrm{mL}$ of $0.05 \%$ picric acid was added to each flask and the mixture was diluted to the volume with chloroform and mixed well. After 5 min the absorbance of each solution was measured at $415 \mathrm{~nm}$ against a reagent blank prepared simultaneously. 


\section{Procedure for tablets}

The content of ten tablets each containing $400 \mathrm{mg}$ ALB was weighed accurately and ground into a fine powder. An accurately weighed quantity equivalent to $100 \mathrm{mg}$ of ALB was transferred into a $100 \mathrm{~mL}$ calibrated flask and dissolved in $60 \mathrm{~mL}$ of DCM. The content was shaken thoroughly for 15-20 min, diluted to the mark with DCM, mixed well, and filtered using a Whatman No. 42 filter paper. The first $10 \mathrm{~mL}$ portion of the filtrate was discarded, and a suitable aliquot of the filtrate $\left(1000 \mu \mathrm{g} \mathrm{mL}^{-1}\right)$ was diluted to get working concentration of $400 \mu \mathrm{g} \mathrm{mL}^{-1}$ with DCM in method A, and analyzed by taking an appropriate volume.

In method B, an accurately weighed quantity of tablet powder equivalent to $10 \mathrm{mg}$ of ALB was transferred into a $100 \mathrm{~mL}$ calibrated flask and dissolved in $60 \mathrm{~mL}$ of chloroform, as described above using chloroform and steps described above were applied to get a working concentration of $60 \mu \mathrm{g} \mathrm{mL} \mathrm{m}^{-1}$ before it was analyzed by taking a suitable aliquot.

\section{Procedure for selectivity study}

Selectivity was evaluated by using placebo blank and synthetic mixture analysis. A placebo blank, consisting of starch (20 mg), acacia (25 mg), hydroxyl cellulose $(20 \mathrm{mg})$, sodium citrate $(30 \mathrm{mg})$, talc $(20 \mathrm{mg})$, magnesium stearate $(25 \mathrm{mg})$ and sodium alginate $(20 \mathrm{mg})$ was prepared by thorough mixing and its solution was prepared as described under "Procedure for tablets", and then subjected to analysis.

A synthetic mixture was prepared by adding $10 \mathrm{mg}$ of pure ALB to $8 \mathrm{mg}$ of the above mentioned placebo blank, and the mixture was homogenized. Following the same procedure for tablets, the synthetic mixture solution was prepared, and a suitable aliquot was subjected to analysis by both methods ( $\mathrm{n}=3$ ), after appropriate dilution.

\section{RESULTS AND DISCUSSION}

\section{Reaction mechanism}

The chemistry involved in the proposed method is the charge-transfer complex formed by the electronic transition to an excited state where the transfer of electronic charge from donor to acceptor moiety takes place partially. As a result, the transition in this excitation energy occurs very frequently in the visible region of the electromagnetic spectrum (Abou, 2000). This produces the usually intense color characteristic of these complexes. Therefore, ALB, a nitrogenous base acting as n-donor was made to react with iodine ( $\sigma$-acceptor) and picric acid
( $\pi$-acceptor) to produce colored charge-transfer complexes in dichloromethane and chloroform, respectively.

In method A, ALB reacts with the reagent and gives a wine red chromogen that exhibits a maximum absorption at $380 \mathrm{~nm}$ in dichloromethane medium. This can be attributed to the formation of charge-transfer complex between ALB (D Figure 2) and iodine followed by the formation of radical ion, which was probably due to the dissociation of (ALB-iodine) complex in dichloromethane. The interaction between the donor and acceptor occurs according to the Figure 4 below:

$$
\begin{aligned}
& \mathrm{D}+\mathrm{I}_{2} \rightleftharpoons \mathrm{D}-\mathrm{I}^{+} \mathrm{I}^{-} \rightleftharpoons\left[\mathrm{D}-\mathrm{I}^{+}\right]^{-}+\mathrm{I}^{-} \stackrel{+\mathrm{I}_{2}}{\rightleftharpoons} \mathrm{I}_{3}^{-} \\
& \begin{array}{ccc}
\text { Outer } & \text { Inner } & \text { Tri-iodide } \\
\text { complex } & \text { complex } & \text { che }
\end{array} \\
& \text { charge-transfer }
\end{aligned}
$$

FIGURE 2 - Reaction pathway for the formation of CT complex between ALB and $\mathrm{I}_{2}$ in dichloromethane.

Picric acid, a trinitrophenol, reacts with electron donor molecule to forms charge transfer and proton transfer complexes. It was used for the determination of some amine derivatives through formation of intense yellow colored complex (Ebeid et al., 1998; Regulska, Tarasiewicz, Puzanowska, 2002; El-Mammli, 2003; El- Yazbi et al., 2003; Abdel-Hay et al., 2004; Karuna et al., 2006; Rajendra, Basavaiah, Vinay, 2011; Johnson, Ukpe, 2011; Pinderjit, Rajanish, Harinder, 2011; Sameer, Basavaiah, 2011; Prashanth, Basavaiah, 2012; Raghu, Basavaiah, 2012).

In method B, the interaction of ALB with PA in chloroform at room temperature gave an intense yellow colored chromogen with strong absorption at $415 \mathrm{~nm}$ due to the formation of the free radical anion. The interaction between ALB (D Figure 3), an n-donor and picric acid (A), a $\pi$-acceptor, is a charge transfer complexation reaction followed by the formation of radical ions according to the following scheme (Figure 5).

$$
\begin{aligned}
\mathrm{D}^{\bullet}+\mathrm{A} & \rightarrow[\mathrm{D} \bullet \rightarrow \mathrm{A}] \rightarrow \mathrm{D}^{\bullet+}+\mathrm{A}^{\bullet-} \\
{[\text { Donor }+ \text { Acceptor }} & \rightarrow \text { Complex } \rightarrow \text { Radical ion }]
\end{aligned}
$$

FIGURE 3 - Reaction pathway for the formation of electron donor-acceptor complex and radical ion between ALB and picric acid.

\section{Absorption spectra}

The reaction of iodine or picric acid with ALB results in the formation of intense wine red or yellow colored 
product. The absorption of colored products was recorded at $360-480 \mathrm{~nm}$ against the corresponding reagent blank solutions. The resulting colored charge-transfer complexes showed maximum absorbance at $380 \mathrm{~nm}$ and $415 \mathrm{~nm}$ for ALB- $\mathrm{I}_{2}$ and ALB-PA, respectively (Figures $4 \mathrm{a}, 4 \mathrm{~b}$ ).

(a)

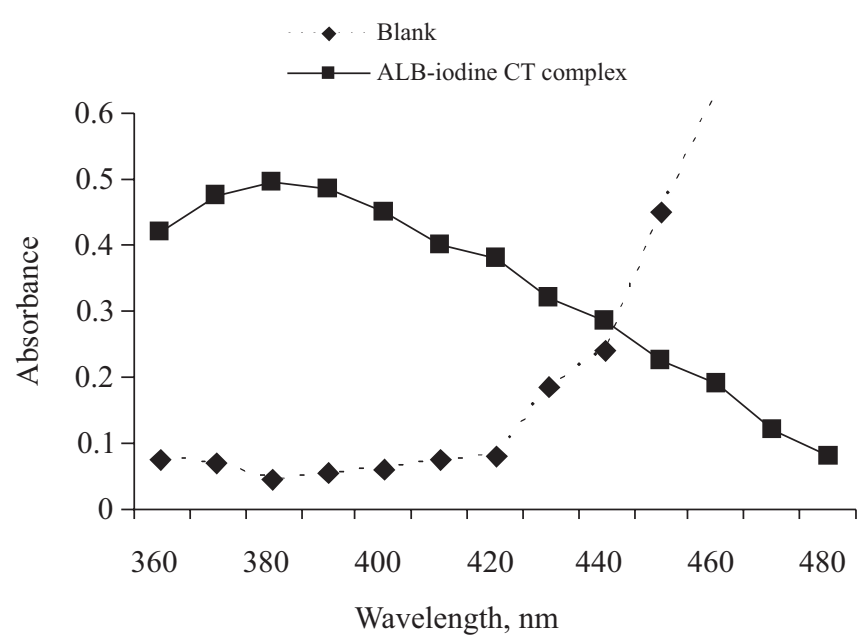

(b)



FIGURE 4 - (a) Absorption spectra of ALB-iodine CT complex (畐) $\left[120 \mu \mathrm{g} \mathrm{mL}^{-1} \mathrm{ALB}\right]$ against blank solution $(\diamond)$; (b) Absorption spectra of ALB-PA CT complex (ם) [30 $\mu \mathrm{g} \mathrm{mL}^{-1}$ ALB] against blank solution ( $\mathbf{A})$.

\section{The effect of different experimental variables}

Experimental variables were optimized in order to achieve the intense color, maximum sensitivity and stability and adherence to Beer's law.

\section{Effect of reagent concentration}

The effect of the reagent concentration on the color intensity at the optimum wavelength was studied by adding different amounts of iodine or PA to a fixed concentration of ALB. It was found that $1 \mathrm{~mL}$ of $0.3 \%$ iodine and $1 \mathrm{~mL}$ of $0.05 \%$ PA was sufficient for the production of maximum and reproducible color intensity in method $\mathrm{A}$ and method $\mathrm{B}$, respectively (Figures 5a, 5b).
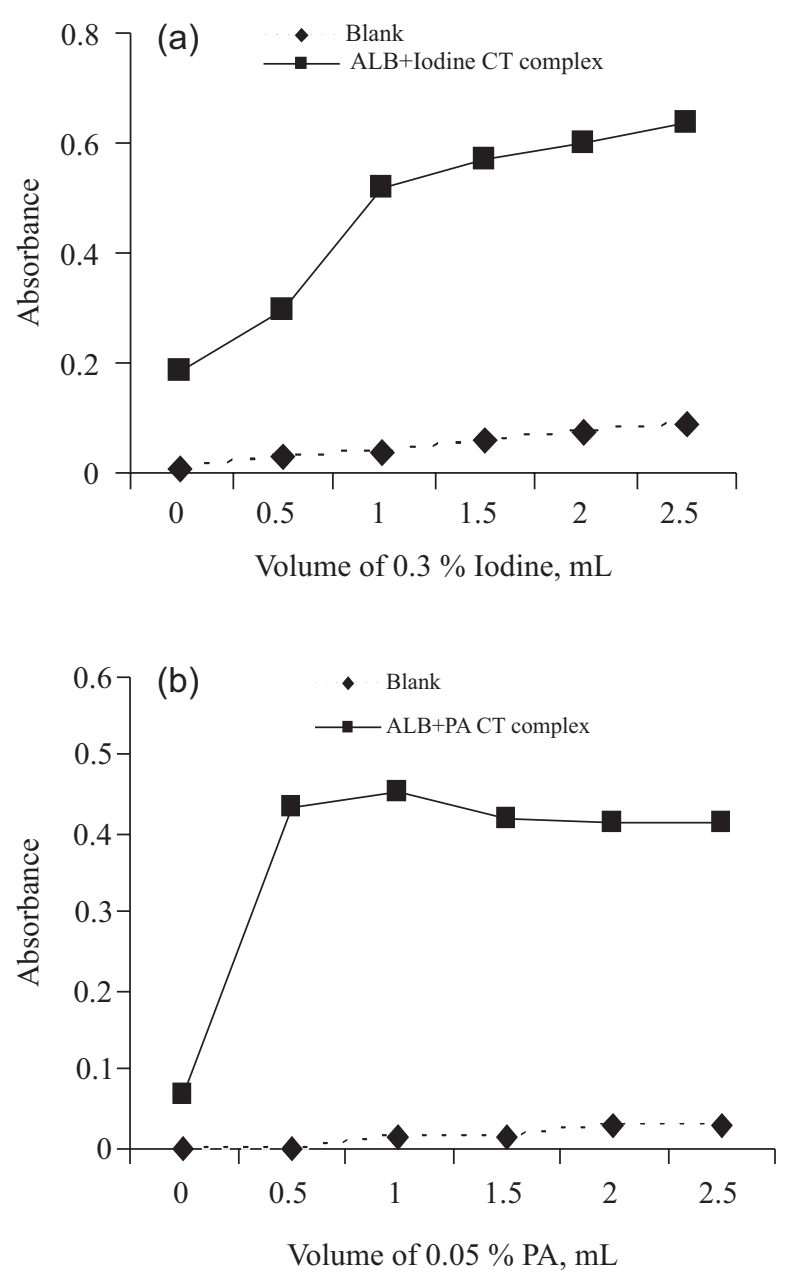

FIGURE 5 - (a) Effect of the iodine concentration for method A (120 $\left.\mu \mathrm{g} \mathrm{mL}^{-1} \mathrm{ALB}\right)$; (b) Effect of the picric acid concentration for method B (30 $\left.\mu \mathrm{g} \mathrm{mL}^{-1} \mathrm{ALB}\right)$.

\section{Effect of solvent}

In order to select the suitable solvent for chargetransfer complex formation, the reaction of ALB with $\mathrm{I}_{2}$ or PA was carried out in different solvents such as DCM, chloroform, acetonitrile, methanol, 1,2-dichloroethane, 1,4-dioxane and benzene. The DCM was found to be ideal for method A and chloroform for method B (Figures $6 \mathrm{a}, 6 \mathrm{~b})$. Similarly, the effect of the diluting solvent was studied for both methods and the results showed that DCM and chloroform are ideal for methods A and B, respectively. 


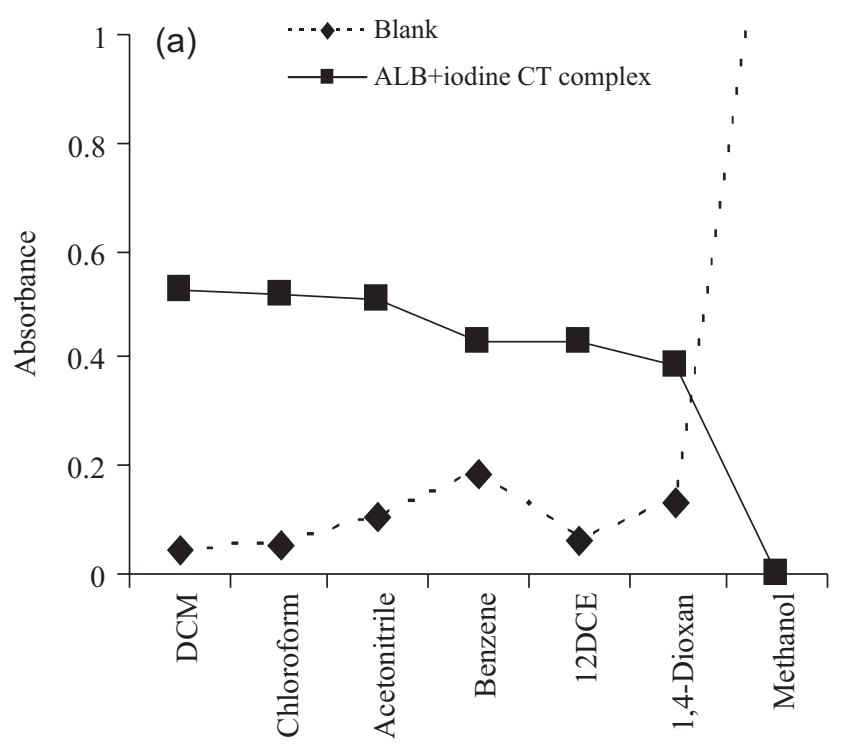

Solvents

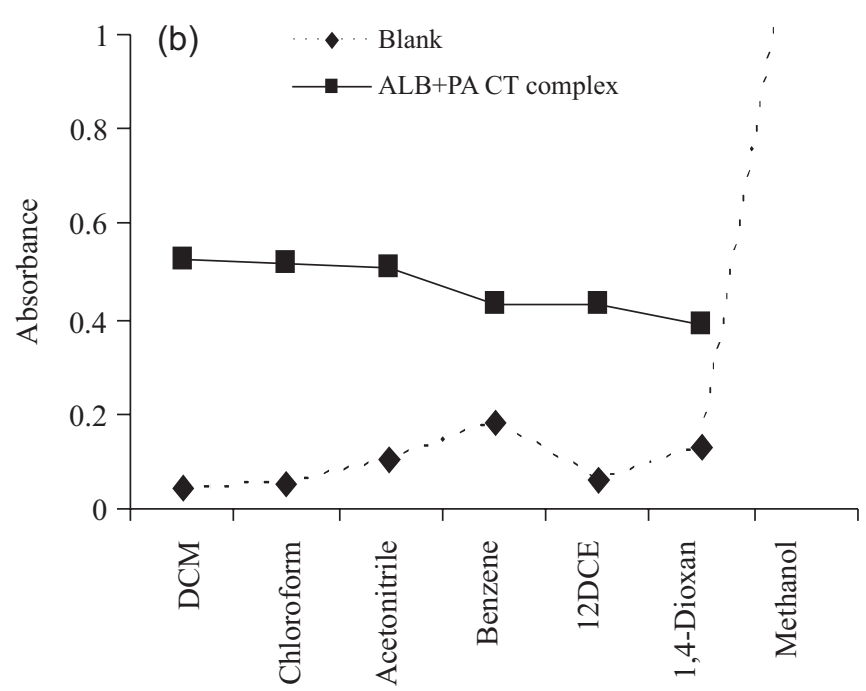

Solvents

FIGURE 6 - (a) Effect of solvent for method A $\left(120 \mu \mathrm{g} \mathrm{mL}^{-1}\right.$ ALB); (b) Effect of solvent for method B (30 $\left.\mu \mathrm{g} \mathrm{mL}^{-1} \mathrm{ALB}\right)$.

\section{Effect of reaction time, and stability of color}

The optimum reaction time was determined by following the color development upon the addition of reagent solution to the ALB solution at room temperature. Complete color development was attained after $5 \mathrm{~min}$ with $\mathrm{I}_{2}$ while the reaction with PA was instantaneous. The absorbance of these radical anions remained stable for at least 30 and 120 min for method $\mathrm{A}\left(\mathrm{I}_{2}\right)$ and method $\mathrm{B}$ (PA), respectively.

\section{Stoichiometric relationship}

Job's method of continuous variations of equimolar solutions was employed to establish the stoichiometry of formed CT complexes. Solutions equivalent to $1.51 \times 10^{-3}$ M ALB and $\mathrm{I}_{2}$ were prepared in DCM in method A, and $2.26 \times 10^{-4} \mathrm{M}$ ALB and PA were prepared in method B by dissolving the calculated quantities in chloroform. A series of solutions was prepared in which the total volume of ALB and reagent was kept at $2.5 \mathrm{~mL}$ in $5 \mathrm{~mL}$ calibrated flasks. The solutions were mixed well; the volume was completed to the mark with respective organic solvent. The absorbance of the resulting solution was measured after $5 \mathrm{~min}$ at the respective wavelengths of maximum absorbance against the respective organic solvent as blanks. The resulting graph (Figures 7a, 7b) showed that the interaction occurs on an equimolar basis (1:1 reaction stoichiometry), owing to the presence of one basic nitrogen containing group.

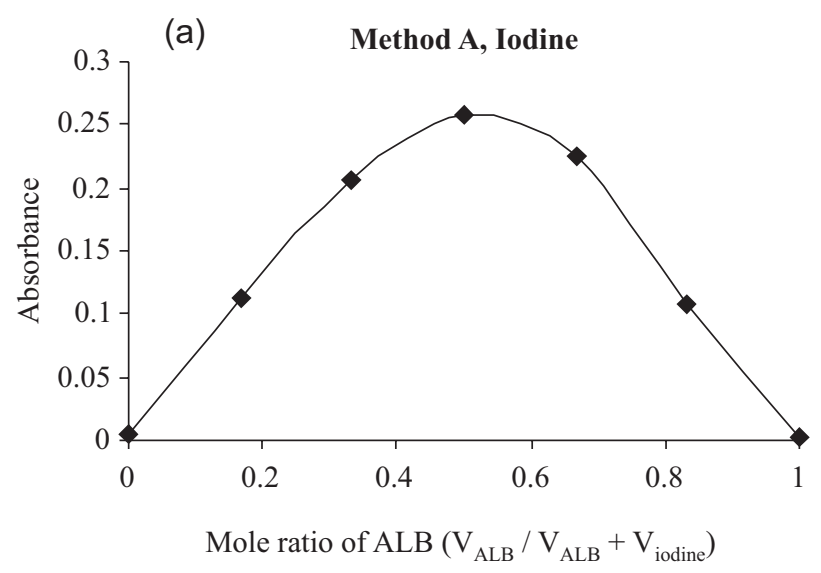

(b)

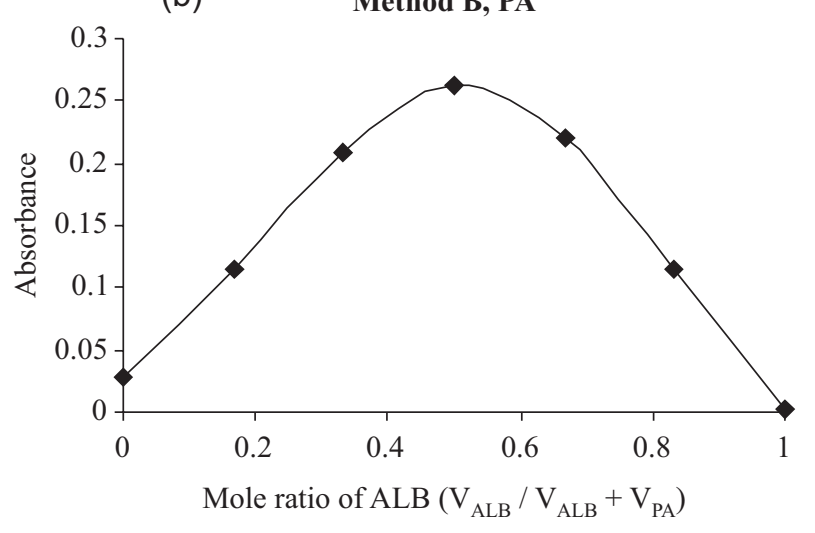

FIGURE 7 - Job's Plot: (a) $[\mathrm{ALB}]$ and $\left[\mathrm{I}_{2}\right]=1.51 \times 10^{-3} \mathrm{M}$ and (b) $[\mathrm{ALB}]$ and $[\mathrm{PA}]=2.261 \times 10^{-4} \mathrm{M}$.

\section{METHOD VALIDATION}

\section{Analytical data}

The linear regression equations were obtained by the method of least squares, and the Beer's law range, molar 
absorptivity, correlation coefficient, confidence limits for slope and intercept for both methods are given in Table I. The detection limit (LOD) and limit of quantification (LOQ) were calculated by using the following equations (ICH Harmonised Tripartite Guideline, 2005).

$\mathrm{LOD}=3.3 \mathrm{~S} /$ slope and $\mathrm{LOQ}=10 \mathrm{~S} /$ slope

where, $\mathrm{S}$ is the standard deviation of the absorbance of seven blank readings.

\section{Accuracy and precision}

In order to determine the accuracy and precision of the proposed methods, pure ALB solution at three different concentration levels (within working range) were prepared and analyzed in seven replicates during the same day (intra-day precision) and on five consecutive days (interday precision) and the results are presented in Table II. The percentage relative error ( $\mathrm{RE} \%$ ) was $\leq 2.60$, which indicates that the accuracy of the methods is satisfactory.

TABLE I - Sensitivity and regression parameters

\begin{tabular}{|c|c|c|}
\hline Parameter & Method A & Method B \\
\hline$\overline{\lambda_{\max }, \mathrm{nm}}$ & 380 & 415 \\
\hline Color stability, min. & 30 & 120 \\
\hline Linear range, $\mu \mathrm{g} \mathrm{mL}^{-1}$ & $8.0-240$ & $2.4-42$ \\
\hline Molar absorptivity $(\varepsilon), \mathrm{L} \mathrm{mol}^{-1} \mathrm{~cm}^{-1}$ & $1.17 \times 10^{3}$ & $5.22 \times 10^{3}$ \\
\hline Sandell sensitivity ${ }^{*}, \mu \mathrm{g} \mathrm{cm}^{-2}$ & 0.2273 & 0.0509 \\
\hline Limit of detection (LOD), $\mu \mathrm{g} \mathrm{mL}^{-1}$ & 0.69 & 0.10 \\
\hline Limit of quantification (LOQ), $\mu \mathrm{g} \mathrm{mL}{ }^{-1}$ & 2.08 & 0.30 \\
\hline \multicolumn{3}{|l|}{ Regression equation, $\mathrm{Y}^{* *}$} \\
\hline Intercept (a) & 0.0515 & 0.0137 \\
\hline Slope (b) & 0.0036 & 0.0193 \\
\hline Standard deviation of a $\left(\mathrm{S}_{\mathrm{a}}\right)$ & $9.98 \times 10^{-2}$ & $9.98 \times 10^{-2}$ \\
\hline Standard deviation of $b\left(\mathrm{~S}_{\mathrm{b}}\right)$ & $5.0 \times 10^{-4}$ & $2.24 \times 10^{-3}$ \\
\hline Variance $\left(\mathrm{Sa}^{2}\right)$ & $9.96 \times 10^{-3}$ & $9.96 \times 10^{-3}$ \\
\hline Regression coefficient (r) & 0.9991 & 0.9984 \\
\hline
\end{tabular}

*Limit of determination as the weight in $\mu \mathrm{g} \mathrm{mL} \mathrm{m}^{-1}$ of solution, which corresponds to an absorbance of $\mathrm{A}=0.001$ measured in a cuvette of cross-sectional area $1 \mathrm{~cm}^{2}$ and $1=1 \mathrm{~cm}$.

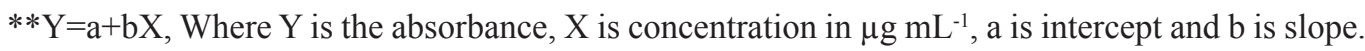

TABLE II - Evaluation of intra-day and inter-day accuracy and precision

\begin{tabular}{|c|c|c|c|c|c|c|c|}
\hline \multirow[b]{2}{*}{ Method } & \multirow{2}{*}{$\begin{array}{l}\text { ALB Taken } \\
\left(\left(\mu \mathrm{g} \mathrm{mL}^{-1}\right)\right.\end{array}$} & \multicolumn{3}{|c|}{ Intra-day accuracy and precision $(n=7)$} & \multicolumn{3}{|c|}{ Inter-day accuracy and precision $(n=7)$} \\
\hline & & $\begin{array}{l}\text { ALB Found }{ }^{a} \\
\left(\mu g \mathrm{~mL}^{-1}\right)\end{array}$ & $\begin{array}{c}\text { RSD }^{\mathrm{b}} \\
\%\end{array}$ & $\begin{array}{l}\mathbf{R E}^{\mathbf{c}} \\
\%\end{array}$ & $\begin{array}{l}\text { ALB found } \\
\left(\mu \mathrm{g} \mathrm{mL}^{-1}\right)\end{array}$ & $\begin{array}{c}\text { RSD }^{\mathbf{b}} \\
\%\end{array}$ & $\begin{array}{l}\mathbf{R E}^{\mathrm{c}} \\
\%\end{array}$ \\
\hline \multirow{3}{*}{ A } & 20.0 & 19.65 & 0.45 & 1.70 & 20.40 & 0.91 & 1.99 \\
\hline & 80.0 & 81.01 & 0.18 & 1.26 & 81.70 & 1.43 & 2.13 \\
\hline & 200.0 & 203.06 & 0.25 & 1.53 & 204.09 & 1.29 & 2.05 \\
\hline \multirow{3}{*}{ B } & 12.0 & 12.12 & 0.54 & 0.95 & 12.3 & 1.79 & 2.60 \\
\hline & 24.0 & 24.28 & 0.96 & 1.16 & 24.5 & 2.34 & 2.08 \\
\hline & 36.0 & 36.45 & 0.42 & 1.25 & 36.52 & 1.84 & 1.44 \\
\hline
\end{tabular}

${ }^{\mathrm{a}}$ Mean value of 7 determinations; ${ }^{\mathrm{b}}$ Relative standard deviation (\%); ${ }^{\mathrm{c}}$ Relative error (\%). 
Percentage relative standard deviation (RSD \%) for intraday was $\leq 0.96$ and for inter-day it was $\leq 2.34$ indicating repeatability and usefulness of the proposed methods in the analysis.

\section{Selectivity}

In order to evaluate the selectivity of the proposed methods for the analysis of pharmaceutical formulations, the effect of the presence of common excipients was tested for possible interference in the assay by placebo blank and synthetic mixture analyses and no significant interference was observed from these excipients. The percent recoveries of ALB were 98.3 \pm 2.3 and 101.2 \pm 2.8 for method A and B respectively. The placebo blank absorbance was similar to reagent blank absorbance in both methods. This confirms the selectivity of the methods in the presence of the common tablet adjuvants.

\section{Robustness and ruggedness}

To determine the robustness of the proposed methods, two important experimental variables: reagent volume and reaction time were slightly varied and the effect of these changes on the absorbance of the CT complex was studied. The results of this effect are presented in Table III and indicated that the proposed methods are robust. Method ruggedness was evaluated by performing the analysis following the general procedures by three different analysts and on three different spectrophotometers by the same analyst. From the \% RSD values presented in Table III, it is concluded that the proposed methods are rugged.

\section{Recovery studies}

Accuracy of the proposed methods was further ascertained via standard-addition technique. Pre-analyzed tablet powder (ABD 400, Alworm-400 and Bandy-400) was spiked with pure ALB at three different concentration levels $(50,100$, and $150 \%$ of the quantity present in the tablet) and the total was found by the proposed methods. The results of the recovery study presented in Table IV indicate that the common tablet excipients did not interfere in the assay procedures.

\section{Application for tablets}

The proposed methods were applied to the determination of ALB in tablets (Table V). The results obtained were statistically compared with those of the official method (British Pharmacopoeia, 2009) by applying the Student's $t$-test for accuracy and $F$-test for precision. The official method describes a potentiometric titration with perchloric acid in formic acid-acetic acid medium. As can be seen from Table $\mathrm{V}$, the calculated $t$ and $F$-values at $95 \%$ confidence level did not exceed the tabulated values of 2.78 and 6.39 respectively, for four degrees of freedom. The results showed that there is no difference between the proposed methods and the official method with respect to accuracy and precision.

\section{CONCLUSIONS}

Two moderately sensitive, extraction-free, rapid and cost-effective spectrophotometric methods based on

TABLE III - Method robustness and ruggedness expressed as intermediate precision

\begin{tabular}{|c|c|c|c|c|c|c|c|}
\hline \multirow[b]{3}{*}{ Method } & \multirow[b]{3}{*}{$\begin{array}{c}\text { ALB taken } \\
\left(\mu \mathrm{g} \mathrm{mL}^{-1}\right)\end{array}$} & \multicolumn{4}{|c|}{ Method Robustness } & \multicolumn{2}{|c|}{ Method Ruggedness } \\
\hline & & \multicolumn{4}{|c|}{ Parameters altered } & \multirow[b]{2}{*}{$\begin{array}{l}\text { Inter-analysts } \\
\quad(\% \text { RSD }) \\
(n=4)\end{array}$} & \multirow[b]{2}{*}{$\begin{array}{c}\text { Inter- } \\
\text { instruments } \\
\text { \%RSD), } \\
(\mathbf{n}=4)\end{array}$} \\
\hline & & $\begin{array}{c}\text { Volume of } \\
\text { iodine }^{\mathrm{a}} \\
\text { \%RSD } \\
(\mathbf{n}=3)\end{array}$ & $\begin{array}{c}\text { Volume of } \mathbf{P A}^{\mathbf{b}} \\
\text { \%RSD } \\
(\mathbf{n}=\mathbf{3})\end{array}$ & $\begin{array}{c}\text { Reaction time }^{\mathrm{a}} \\
\% \text { RSD } \\
(\mathrm{n}=\mathbf{3})\end{array}$ & $\begin{array}{c}\text { Reaction time }^{\mathrm{b}} \\
\% \text { RSD } \\
(\mathrm{n}=\mathbf{3})\end{array}$ & & \\
\hline \multirow{3}{*}{ A } & 20.0 & 1.26 & 1.06 & 1.61 & 1.12 & 1.52 & 1.63 \\
\hline & 80.0 & 1.78 & 1.21 & 1.54 & 1.25 & 2.03 & 1.84 \\
\hline & 200.0 & 2.09 & 2.03 & 2.13 & 2.33 & 3.12 & 2.98 \\
\hline \multirow{3}{*}{ B } & 12.0 & 0.93 & 1.27 & 1.74 & 1.07 & 1.12 & 1.36 \\
\hline & 24.0 & 0.85 & 1.21 & 1.18 & 1.08 & 0.96 & 1.21 \\
\hline & 36.0 & 0.52 & 2.10 & 1.02 & 2.09 & 0.89 & 2.35 \\
\hline
\end{tabular}

a \& b In both methods, the volumes of reagent were $1 \pm 0.1 \mathrm{~mL} .{ }^{\mathrm{a} \& \mathrm{~b}} \mathrm{The}$ reaction times were $5 \pm 1 \mathrm{~min}$. [ ${ }^{\mathrm{a}} \mathrm{Method} \mathrm{A}$ and $\left.{ }^{\mathrm{b}} \mathrm{Method} \mathrm{B}\right]$ 
TABLE IV - Results of recovery study via standard addition method with tablet

\begin{tabular}{|c|c|c|c|c|c|}
\hline Method & Tablet studied & $\begin{array}{c}\text { ALB in tablet } \\
\mu \mathrm{g} \mathrm{mL^{-1 }}\end{array}$ & $\begin{array}{l}\text { Pure ALB added } \\
\qquad \mu \mathrm{g} \mathrm{mL} \mathrm{mL}^{-1}\end{array}$ & $\begin{array}{l}\text { Total found } \\
\qquad \mathrm{gg} \mathrm{mL^{-1 }}\end{array}$ & $\begin{array}{c}\text { Pure AIB } \\
\text { recovered* } \\
\text { Percent } \pm \text { SD }\end{array}$ \\
\hline \multirow{9}{*}{ A } & \multirow{3}{*}{ Alworm 400} & 80.09 & 40 & 119.9 & $99.6 \pm 0.53$ \\
\hline & & 80.09 & 80 & 160.2 & $100.2 \pm 0.98$ \\
\hline & & 80.09 & 120 & 200.9 & $100.7 \pm 0.59$ \\
\hline & \multirow{3}{*}{$\mathrm{ABD} 400$} & 79.6 & 40 & 119.9 & $99.3 \pm 0.52$ \\
\hline & & 79.6 & 80 & 159.7 & $100.1 \pm 0.97$ \\
\hline & & 79.6 & 120 & 199.5 & $99.9 \pm 0.59$ \\
\hline & \multirow{3}{*}{ Bandy 400} & 79.84 & 40 & 120.4 & $101.4 \pm 1.92$ \\
\hline & & 79.84 & 80 & 160.6 & $100.9 \pm 0.98$ \\
\hline & & 79.84 & 120 & 199.5 & $99.7 \pm 0.59$ \\
\hline \multirow{9}{*}{ B } & \multirow{3}{*}{ Alworm 400} & 14.79 & 7.2 & 21.95 & $99.4 \pm 0.49$ \\
\hline & & 14.79 & 14.4 & 29.34 & $101.1 \pm 1.19$ \\
\hline & & 14.79 & 21.6 & 36.43 & $100.2 \pm 0.54$ \\
\hline & \multirow{3}{*}{$\mathrm{ABD} 400$} & 14.44 & 7.2 & 21.66 & $100.3 \pm 0.84$ \\
\hline & & 14.44 & 14.4 & 28.95 & $100.8 \pm 0.89$ \\
\hline & & 14.44 & 21.6 & 36.42 & $101.8 \pm 0.54$ \\
\hline & \multirow{3}{*}{ Bandy 400} & 14.60 & 7.2 & 21.8 & $99.5 \pm 0.98$ \\
\hline & & 14.60 & 14.4 & 29.1 & $100.8 \pm 1.48$ \\
\hline & & 14.60 & 21.6 & 36.1 & $99.4 \pm 0.53$ \\
\hline
\end{tabular}

*Mean value of three determinations

TABLE V - Results of analysis of tablets by the proposed methods

\begin{tabular}{|c|c|c|c|c|}
\hline \multirow{3}{*}{ Tablets analyzed } & \multirow{3}{*}{$\begin{array}{l}\text { Label claim, } \\
\text { mg/tablet }\end{array}$} & \multicolumn{3}{|c|}{ Found" (Percent of label claim \pm SD) } \\
\hline & & \multirow{2}{*}{ Reference method } & \multicolumn{2}{|c|}{ Proposed methods } \\
\hline & & & Method A & Method B \\
\hline & & & $100.12 \pm 0.83$ & $102.7 \pm 2.04$ \\
\hline \multirow[t]{3}{*}{ Alworm 400} & 400 & $101.3 \pm 1.02$ & $t=2.01$ & $t=1.37$ \\
\hline & & & $F=1.51$ & $F=4.0$ \\
\hline & & & $99.5 \pm 1.13$ & $100.3 \pm 0.47$ \\
\hline \multirow[t]{3}{*}{ ABD 400} & 400 & $99.8 \pm 1.17$ & $t=0.41$ & $t=0.89$ \\
\hline & & & $F=1.07$ & $F=6.2$ \\
\hline & & & $99.8 \pm 0.44$ & $101.4 \pm 1.65$ \\
\hline \multirow[t]{2}{*}{ Bandy 400} & 400 & $100.8 \pm 0.91$ & $t=2.23$ & $t=0.71$ \\
\hline & & & $F=4.93$ & $F=3.29$ \\
\hline
\end{tabular}

"Mean value of five determinations. Tabulated $t$-value at the $95 \%$ confidence level is 2.78 . Tabulated $F$-value at the $95 \%$ confidence level is 6.39 .

charge-transfer complex reactions were developed and validated for the determination of ALB. The reagents utilized in the proposed methods are cheap, readily available, and quite stable in solution unlike many reagents used in above reported methods. The procedures do not involve any critical reaction conditions such as rigid $\mathrm{pH}$ control, tedious and time-consuming extraction or heating step. The methods are more sensitive than many of the reported spectrophotometric methods and applicable over wide linear dynamic ranges. The methods are free from interferences from the common excipients. The statistical parameters and the recovery data reveal good accuracy and precision of the methods. The methods have many other advantages such as reduced cost, simplicity, and speed. 
Hence, the methods can be used in routine analysis of the drug in quality control laboratories and pharmaceutical analysis.

\section{ACKNOWLEDGEMENTS}

Authors express their gratitude to the quality control manager, Cipla India, Ltd., Mumbai for gift sample of pure Albendazole. Prof. K. Basavaiah thanks UGC, New Delhi for the award of UGC-BSR faculty fellowship. One of the authors (NS), thank the authorities of the University of Mysore, Mysore, for providing research facilities and for awarding a UGC NON-NET Ph.D fellowship.

\section{REFERENCES}

ABD EL-SATTAR, O.I.; EL-ABASAWY, N.M.; ABDELRAZEQ, S.A.; ISMAIL, M.M.; ATTIA, K.A.; RASHED, N.S. Stability indicating method for determination of albendazole and fenbendazole in the presence of their degradates. Egypt. J. Biomed. Sci., v.18, p.105-109, 2005.

ABDEL-HAY, M.H.; SABRY, S.M.; BARARY, M.H.; BELAL, T.S. Spectrophotometric determination of bisacodyl and piribedil. Anal. Lett., v.37, p.247-262, 2004.

ATTIA, F.M. Use of charge-transfer complex formation for the spectrophotometric detremination of nortrityline. Farmaco, v.59, p.659-664, 2000.

ANIL, W.; SUBHASH, G.; ROSHAN, I.; BADRI, P.N. Validated liquid chromatographic method for simultaneous estimation of albendazole and ivermectin in tablet dosage form. Indian J. Chem. Technol., v.15, p.617-620, 2008.

ATKOSAR ZEKI; ALTIOKKA; GOEKSEL. The determination of albendazole by flow injection analysis method using uv-detection and HPLC method in suspensions. J. Liq. Chromatog. Related Technol., v.29, p.849-856, 2006.

BASAVAIAH, K.; THARPA, K.; RAJENDRA PRASAD, N.; HIRIYANNA, S.G.; VINAY, K.B. Simple, sensitive and rapid spectrophotometric determination of albendazole based on redox and complex formation using N-bromosuccinimide. Proc. Indian Natl. Sci. Acad., v.75, p.1-6, 2009 .

BASAVAIAH, K.; NAGEGOWDA, P. Three new methods for the assay of albendazole using N-chlorosuccinimide. J. Sci. Ind. Res., v.63, p.835-841, 2004.
BASAVAIAH, K.; NAGEGOWDA, P.; RAMAKRISHNA, V. Titrimetric and spectrophotometric methods for the assay of albendazole in non-aqueous medium. Proc. Indian Natl. Sci. Acad., v.74, p.271-276, 2004.

BASAVAIAH, K.; PRAMEELA, H.C. Kinetic and titrimetric determination of albendazole using bromate and methyl orange. Indian J. Pharm. Sci., v.67, p.57-60, 2005.

BASAVAIAH, K.; PRAMEELA, H.C. Titrimetric and spectrophotometric determination of albendazole with bromate and methyl orange. Oxid. Commun., v.27, p.177$181,2004$.

BASAVAIAH, K.; PRAMEELA, H.C. Use of an oxidation reaction for the quantitative determination of albendazole with chloramine-T and acid dyes. Anal. Sci., v.19, p.779$784,2003 \mathrm{a}$.

BASAVAIAH, K.; PRAMEELA, H.C. Two simple methods for the estimation of albendazole and its dosage forms using chloramine-T. Farmaco, v.58, p.527-534, 2003b.

BASAVAIAH, K.; RAMAKRISHNA, V.; SOMASHEKAR, B.C.; ANILKUMAR, U.R. Sensitive titrimetric and spectrophotometric methods for the assay of albendazole in pharmaceuticals using sodium periodate. Anal. Chem. Indian J., v.2, p.159-166, 2006.

BASAVAIAH, K.; RAMAKRISHNA, V.; SOMASHEKAR, B.C. Assay of albendazole using N-bromosuccinimide. Indian Pharm., v.5, p.129-136, 2006.

BRITISH PHARMACOPOEIA. Her majesty's stationary office London, 2009. $2094 \mathrm{p}$.

SOTO, C.; CONTREAS, D.; ORELLANA, S.; VANEZ, J.; INES, M. Simultaneous determination of albendazole and praziquantel by second derivative spectrophotometry and multivariated calibration methods in veternary pharmaceutical formulation. Anal. Sci., v.26, p.891-896, 2010 .

DE OLIVEIRA, M.F.; STRADIOTTO, N.R. Voltammetric assay of albendazole in pharmaceutical dosage forms. Anal. Lett., v.34, p.377-387, 2001.

EBEID, M.Y.; EL-KOUSY, N.M.; MOUSA, B.A.; MOHAMMED, N.G., Contribution to the methods of determination of some cardiovascular drugs. Egypt. J. Pharm. Sci., v.9, p.31-43, 1998. 
EL-MAMMLI, M.Y. Spectrophotometric determination of flucloxacillin in pharmaceutical preparations using some nitrophenols as a complexing agent. Spectrochim. Acta. A Mol. Biomol. Spectrosc., v.59, p.771-776, 2003.

EL-YAZBI, F.A.; GAZY, A.A.; MAHGOUB, H.; EL-SAYED, M.A.; YOUSEF, R.M. Spectrophotometric and titrimetric determination of nizatidine in capsules. J. Pharm. Biomed. Anal., v.31, p.1027-1034, 2003.

ESIMONE, C.O.; OMEJE, E.O.; OKOYE, F.B.C.; OBONGA, W.O.; ONAU, B.U. Evidence for the spectroscopic determination of artesunate in dosage form. J. Vector Borne Dis., v.45, p.281-286, 2008.

FREGONEZI-NERY, M.M.; BARACAT, M.M.; KEDORHACKMANN, E.R.M.; PINHEIRO, R.M. Determination of albendazole in oral suspension. Anal. Lett., v.34, p.1255$1263,2001$.

GYURIK, R.J.; THEODORIDES, V.J. Preparation and synthesis of albendazole, U.S. Patent 3915 986, 1975. Chem. Abstr., v.84, p.31074, 1976.

\section{INTERNATIONAL CONFERENCE ON HARMONISATION} OF TECHNICAL REQUIREMENTS FOR REGISTRATION OF PHARMACEUTICALS FOR HUMAN USE. ICH. Harmonised tripartite guideline. Validation of analytical procedures: text and methodology, Q2 (R 1), complementary guideline on methodology dated 06 November 1996, London, incorporated in November 2005. Available at: <www.ich.org/fileadmin/.../ Guidelines/.../Q2_R1/.../Q2_R1_Guideline.pd >.Accessed on: November 1996.

INTERNATIONAL PHARMACOPOEIA. WHO. 3.ed. India: C.B.S. Publishers and Distributors, 1987. v.1, p.130.

JAIME, N.D.; WILLIAM, A.R. Textbook of organic medicinal and pharmaceutical chemistry. 10.ed. New-York: Lippincolt Paven publishers, 1988. p.235-252.

JOHNSON, O.O.; UKPE, A. Spectrophotometric determination of tenofovir disoproxyl fumarate after complexation with ammonium molybdate and picric acid. Int. J. Drug Dev. Res., v.3, p.199-204, 2011.
KAMEL, M.S.; BARSOUM, B.N.; SAYED, R. Spectrophotometric microdetermination of anthelmintic drug in pure form and pharmaceutical formulation by ionpair complexation. J. Appl. Sci. Res., v.4, p.1242-1248, 2008.

KARUNA, T.; NEELIMA, K.; VENKATESHWARULU, G.; YADAGIRISWAMY, P. Spectrophotometric determination of drugs with iodine. J. Sci. Ind. Res., v.65, p.808-811, 2006.

KRISHNAIAH, Y.S.R.; LATHA, K.; KARTHIKEYAN, R.S.; SATYANARAYANA, V. HPLC method for the estimation of albendazole in pharmaceutical dosage forms. Acta Cienc. Indica Chem., v.27, p.161, 2001.

LAURENTIS, N.D.; MLiLlO, M.A.; BRUNO, S. Determination of albendazole as raw material and in tablets by non-aqueous titration with sodium methylate solution. Rev. Farm. Bioquim. Univ. Sao Paulo., v.33, p.23-27, 1997.

LIAWRUANGRATH, B.; LIAWRUANGRATH, S. High performance liquid chromatographic method for the determination of albendazole. ACGC Chem. Res. Commun., v.8, p.45-50, 1998.

MANDAL, C.; BHATTACHARYYA, S.M.; MAITY, A.K.; GUPTA B.K.; GHOSAL, S.K. Determination of albendazole in tablet formulations by uv spectrophotometric method. Indian Drugs, v.29, p.323-324, 1992.

OSWAL, A.; KONDAWAR, M.; PHASE, S.; NAZARKAR, S.; NIKAM, M.; NARKHEDE, H. Validated uv spectrophotometric method for the estimation of albendazole in tablet dosage forms. J. Pharm. Res., v.3, p.1355-1357, 2010 .

PINDERJIT, S.; RAJANISH, K.; HARINDER, S. Sensitive and selective spectrophotometric determination of sertraline in pharmaceuticals using picric acid. Int. J. Pharm. Res. Dev., v.3, p.175-179, 2011.

PRASHANTH, K.N.; BASAVAIAH, K. Simple, sensitive and selective spectrophotometric methods for the determination of atenolol in pharmaceuticals through charge transfer complex formation reaction. Acta Pol. Pharm., v.69, p.213$223,2012$. 
RAGHU, M.S.; BASAVAIAH, K. Optimized and validated spectrophotometric methods for the determination of levocetirizine in pharmaceuticals based on charge transfer reaction. J. Assoc. Arab. U. Basic Appl. Sci., v.12, p.33-41, 2012.

RAJENDRA PRASAD, N.; BASAVAIAH, K.; VINAY, K.B. Optimized and validated spectrophotometric methods for the determination of hydroxyzine hydrochloride in pharmaceuticals and urine using iodine and picric acid. $J$. Serb. Chem. Soc., v.76, p.1551-1560, 2011.

RANG, H.B.; DALE, M.M.; RITHER, J.M. Pharmacology. 4ed. New York: Churchill Livingstone, 1999. p.725-731.

REFAT, S.M.; MOHAMMED, G.G.; FATHI, A. Spectrophotometric determination of albendazole drug in tablets: Spectroscopic characterization of the chargetransfer solid complexes. Chin. J. Chem., v.29, p.324-332, 2011.

REGULSKA, E.; TARASIEWICZ, M.; PUZANOWSKATARASIEWICZ, H. Extractive spectrophotometric determination of some phenothiazines with dipicrylamine and picric acid. J. Pharm. Biomed. Anal., v.27, p.335-340, 2002.

SAMEER A.M.A.; BASAVAIAH, K. Sensitive and selective spectrophotometric determination of gabapentin in capsules using two nitrophenols as chromogenic agents. Int. J. Anal. Chem., v.2011, p.1-10, 2011.

SANE, R.T.; SAMANT, R.S.; JOSHI, M.D.; PURANDALE, S.M.; TEMBE, P.B.; VIHESH, N.G. High performance liquid chromatographic determination of albendazole in pharmaceuticals. Indian Drugs, v.26, p.494-496, 1989a.

SANE, R.T.; GANGAL, D.P.; TENDOLKAR, R.V.; LADAGE, K.D.; KOTHURKAR, R.M. An extractive colorimetric method for the determination of albendazole from pharmaceutical preparations. Indian Drugs, v.26, p.632$635,1989 b$.

SANTOS, L.A.; REGINA, M.T.; MARIOTTI, P.; DE OLIVEIRA, M.F.; ZANONI, M.; MARIA, V.B.; STRADIOTTO, N.R. Study of electrochemical oxidation and determination of albendazole using a glassy carbonrotating disk electrode. Farmaco, v.60, p.671-674, 2005.
SASTRY, C.S.P.; SARMA, V.A.N.; PRASAD, U.V.; LAKSHMI, C.S.R. Note on the estimation of some benzimidazole anthelmintics in pharmaceutical preparations by ion-pair extraction method. Indian Drugs, v.34, p.102-103, 1997.

SEMAHAT, K.; BENIZ, G.; ESMA, K. Development of a spectrofluorimetric method for determination of albendazole in tablets. Anal. Lett., v.41 p.104-107, 2008.

TELLA, A.C.; OLABEMIWO, O.M.; MALWI, M.O.; OBIYENWAL, G.K. Developing a spectrophotometric method for the estimation of albendazole in solid and suspension forms. Int. J. Phys. Sci., v.5, p.379-382, 2010.

THEODORIDES, V.J. Anthelmintic studies. Expermentia, v.32, p.702, 1976.

VARGHESE, S.J.; VASANTHI, P.; RAVI, T.K. Simultaneous densitometric determination of ivermectin and albendazole by high-performance thin layer chromatography. J. Planar Chromatogr., v.24, p.344-347, 2011.

ZARAPKAR, S.S.; DESHPANDE, D.M. Colorimetric determination of albendazole and its dosage forms. Ind. $J$. Pharm. Sci., v.50, p.296-297, 1988.

ZHAO, G.; LI, H.; LIU, Y.; WANG, Y. Application of charge transfer reaction between albendazole and chloranilic acid. Fenxi Ниахие, v.29, p.389-400, 2001.

ZHAO, G.Y.; WU, H.; DONG, S.L.; DU, L.M. Study on the inclusion interaction of methylated-b-cyclodextrins with albendazole by spectrofluorimetry and its application. Chin. Chem. Lett., v.19, p.951-954, 2008.

ZUHRI, A.A.; HUSSEIN, A.I.; MUSMAR, M.J.; YAISH, $\mathrm{S}$. Adsorptive stripping voltammetric determination of albendazole at a hanging mercury drop electrode. Anal. Lett., v.32, p.2965-2975, 1992.

Received for publication on $04^{\text {th }}$ July 2013 Accepted for publication on 14 ${ }^{\text {th }}$ April 2014 